\title{
Nasopharyngeal Cancer pTO TNM Finding v8
}

National Cancer Institute

\section{Source}

National Cancer Institute. Nasopharyngeal Cancer pT O TNM Finding v8. NCI Thesaurus. Code C132797.

No tumor identified, but EBV-positive cervical node(s) involvement is present. (from AJCC 8th Ed.) 